\title{
Weten en doen, willen en kunnen
}

Citation for published version (APA):

Limburg, M. (2004). Weten en doen, willen en kunnen. Maastricht University. https://doi.org/10.26481/spe.20040910ml

Document status and date:

Published: 10/09/2004

DOI:

10.26481/spe.20040910ml

Document Version:

Publisher's PDF, also known as Version of record

\section{Please check the document version of this publication:}

- A submitted manuscript is the version of the article upon submission and before peer-review. There can be important differences between the submitted version and the official published version of record.

People interested in the research are advised to contact the author for the final version of the publication, or visit the DOI to the publisher's website.

- The final author version and the galley proof are versions of the publication after peer review.

- The final published version features the final layout of the paper including the volume, issue and page numbers.

Link to publication

\footnotetext{
General rights rights.

- You may freely distribute the URL identifying the publication in the public portal. please follow below link for the End User Agreement:

www.umlib.nl/taverne-license

Take down policy

If you believe that this document breaches copyright please contact us at:

repository@maastrichtuniversity.nl

providing details and we will investigate your claim.
}

Copyright and moral rights for the publications made accessible in the public portal are retained by the authors and/or other copyright owners and it is a condition of accessing publications that users recognise and abide by the legal requirements associated with these

- Users may download and print one copy of any publication from the public portal for the purpose of private study or research.

- You may not further distribute the material or use it for any profit-making activity or commercial gain

If the publication is distributed under the terms of Article $25 \mathrm{fa}$ of the Dutch Copyright Act, indicated by the "Taverne" license above, 


\section{Weten en doen, willen en kunnen}




\section{colofon}

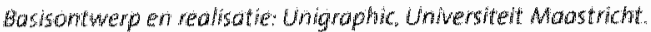

$15 B M 90-5681-216-5$

NuP 876

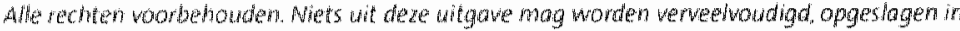

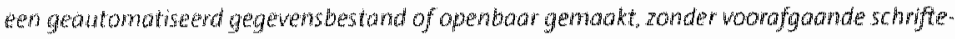
ligke toesteming wan de auteur of witgever. 


\section{Weten en doen, willen en kunnen}

Redle

uitgesproken bij de aanvarding van het ambt van hoog" leraar in de neurologie aan de Universiteit Maastricht op vijidag 10 september 2004

door

Prof. Dr. M. Limburg, MBA 
Meneer de Rector Magnificus.

collegae, familie en vrienden.

\section{Inleiding}

De mogelijk wat filosofisch getinte titel van mijn rede wordt heel wat prozaischer als ik u vertel dat de ondertitel 'De behandeling van acute cerebrovasculaire aandoeningen' is. I $k$ wil het hebben ower wat we weten, over wat we in de praktijk doen, over het willen in dezen en over het kunnen zorgen en behandelen van patiënten met een beroerte. ik ben overtuigd dat we met de huidige kennis maar met betere organisatie, ervoor kunnen zorgen dat jarlijks meer dan duizend Nederlanders minder overlijden aan de gevolgen van een beroerte of hun zelfstandig. heid verliezen. Hoewel ik over cerebrovasculaire ziekten spreek, is veel van mijn verhaal in feite voor de gehele neurologie geldig. We kunnen veel beter. Als wij willen, kunnen we doen wat we weten.

Het latste decennium is bijzonder veel gebeurd op het gebied van de cerebrovasculaire ziekten. We weten meer over het ontstaan, epidemiologie en behandeling. Het bijna volledig therapeutisch nihilisme van 10 tot 15 jaar geleden is voorbij.

Hoewel de perspectieven van de moleculaire biologie en genetica duizelingwekkend zijn, kunnen wij op korte termijn de zorg fors verbeteren. Daar wil ik over praten.

\section{Weten}

Wat weten we inmiddels over ontstaan, wöókomen, voorkómen en behandeling van cerebrovasculaire ziekten?

De uitdrukking CVA ("cerebrovasculair accident") is een wat deftige uitdrukking voor een 'ongeval van de hersenvaten', zonder dat deze duidelijk maakt wat er an de hand is. Ha zal de oude en pretentieloze term beroerte gebruiken. Het geeft niet weel meer aan dat er iets serieus mis is in het hoofd. waarschijnlijk lets met de bloedvaten. Er zijn in Nederland jarlijks ruim 30.000 mensen die een beroerte doormaken. Beroerten wormen de derde doodsoorzaak, naar schatting 1 op elke 10 Nederlanders zal aan een beroerte overlijden en 1 op de 8 zal ooit een beroerte doormaken. Het is een ziekte van de oude dag, de gemiddelde leeftijd is ongeveer 74 jaar. Omdat het zo veel woorkomt, zijn er jaarlijks. meer dan 1000 getroffenen onder 45 jaar.

In $80 \%$ van de gevallen betreft het een infarct, dus een afgesloten 
bloedvat in de hersenen wardoor er weefsel verloren gaat en neurologische uitval ontstat. in 10\% betreft het een bloeding. Dat will zeggen dat er een bloedvatje in de hersenen knapt, bloed het weefsel instroomt en schade veroorzaakt. Een minder waak woorkomende categorle is de subarachnoidale bloeding (ongeveer $5 \%$ van het totaaly, waarbij een uitstulping van een bloedvat (aneurysma') knapt. Ik noem nog het begrip TIA (transient ischemic attack). Dit is voorbijgaande neurologische uitval meestal tot een half uur durend (maar het kan maximaal 24 utur zijn op basis wan een tjjellijk verstopt bloedwat. In het vervolg van mijn rede bespreek ik woomamelijk het beleid bij herseninfarcten, de grootste groep, veel hiervan is ook toepasselijk woor bloedingen. Een beroerte maakt zich kenbaar door het plots ontstaan van neurologische uitval, afhankelijk van de plats waar het letsel in de hersenen ontstaat. Is dit in het gebied van de taal dan kan er een taalstoornis (afasie) ontstaan, is dit in het gebied van de motoriek dan ontstaan er verlammingen. Andere gevolgen kunnen zijn: gewoelsstoomissen. stoornissen in de kennende functies (geheugen, denken, herkennen, ruimtelijke oriëntatie etc), soms min of meer onzichtbaar: neer slachtigheid, concentratie stoomissen, karakterveranderingen. Pijn doet het gewoonijk niet.

Na een jaar is ongeveer eenderde van de getroffenen overleden, vervolgens blift de sterftekans duidelijk verhoogd, met ongeveer $9 \%$ Minder dan de helft van alle patienten is na een jaar in staat voor zichzelf te zorgen. Het is een acute ziekte, die overgaat in een chronisch pro. bleem. Elke fase heeft zijn eigen begeleiding en aanpak nodig.

Voor velen is het een schrikbeeld niet meer voor jezelf te kunnen zorgen maar van anderen afhankelijk te zijn voor de heel gewone dingen in het leven. Ook voor de maatschappij in zijn geheel is dit een zware last. Juist die lange zorgafhankelijkheid die regelmatig het gevolg is van een beroerte, waardoor mensen genoodzaakt zijn op lange termijn in verpleeghuizen of andere instellingen te verblijwen maakt dat dit een kostbare ziekte is. Ongeveer $4 \%$ van het gehele gezondheidszorg budget wordt a an de behandeling wan deze ziekte of zorg woor mensen die aan de gevolgen ervan lijden besteed. Door het invaliderende en chronische karakter van de ziekte is het tevens de grootste oorzalk van invaliditeit op volwassen leeftijd.

In de nabije toekomst mogen we meer mensen met een beroerte verwachten op basis van vergrijzing. Er zijn berekeningen die een toename tot $62 \%$ in 2020 ten opzichte van 1995 voorspellen, maar er zijn ook onderzoeken die lager uitkomen. 
Begrijpen hoe ziektes veroorzakt worden en tot verschijnselen leiden is interessant en noodzakelijk. Maar het is volstrekt onvoldoende om daarmee tot behandeling te komen. Het niet toetsen van hypothesen in een experiment in de praktijk kan tot emstige misstanden aanleiding geven. Een voorbeeld hiervan is de operatie van de hal sslagader. de carotisendarterectomie. Toen ontdekt werd dat herseninfarcten nogal eens werden begeleid door vernauwingen in de bloedtoevoerende vaten, de carotis halsslagaders, was de stap naar operatief verwijderen van die atherosclerose gauw gedaan. Ook in Nederland zijn duizenden mensen geopereerd op grond vam deze redenering. Enkele doorzetters in Europa en de verenigde Staten heben, tegen de stroom in, goed wetenschappelijk onderzoek opgezet. Voor betrekkelijk grote groepen patiënten met een herseninfarct en een wernauwing van de halsslagader werd door middel van loting bepaald of de halssllagader geopereerd zou worden of niet. Alle patienten werden gerume tijd gevolgd om te zien hoe het hen verging. En wat bleek: diegenen met een ernstige vernauwing hadden een zeer duidelijke baat bij de ingreep. Personen met een geringe vernauwing niet. Maar deze personen die dus weinig te winnen hadden bij deze ingreep ondergingen wel de kwade kansen die hieraan verbonden zijn. Dus wel het risico, maar niet het nut. Bilikbaar hadden wij artsen duizenden mensen geopereerd op grond wan onvoldoend bewijs en vele mensen schade berokkend waardoor er ongetwijfeld ook velen overleden zijn. Maar er waren zeker mensen die baat hadden kunnen hebben bij de ingreep maar die niet behandeld waren.

Het is onze taak als artsen om empirisch te toetsen op correcte wijze of ideëen juist zijn en of we patienten daadwerkeiijk helpen. Al te vaak. hoor ik dat een bepaalde behandeling nooit onderzocht kan worden. omdat... bijvoorbeeld het aantal patienten te klein is. Welnu, laat ik duidelijk zijn dat dat niet eenvoudig is Gelukkig zijn or wetenschappelijk onderzoekers die doorzetten, tegen de verdrukking in, soms vele jaren lang. Zij kumen daardoor effecten aantonen die anders niet onderzocht hadden kunnen worden. Deze onderzoekers bewijzen daarmee theel veel mensen een zeer grote dienst. Deze ontwikkeling, waarbij ons handelen gebaseerd is op robuuste empirie wardt ook wel 'evidence based med. cine' genoemd. Het is een uitgangspunt voor ons medisch handelen. De vasculaire neurologe is bij uitstek een vak warin deze methodiek gebruikt kan en moet worden.

Nalast behandelen verdient ook de preventie van beroerten veel aandacht. Op goede gronden schrijveri wij aspirine en soms andere midde- 
len voor, behandelen we een verhoogde bloeddruk en bestrijden we te hoge cholesterol gehalten.

\section{Behandeling}

Ik kom nu op de behandeling van een herseninfarct. We weten inmiddels dat wat we vroeger in de schoolbanken leerden over hersenschade niet waar is. Een hersencel is niet noodzakelijkerwijze geheel dood na enkele miruten zonder zuurstof. Die tijd kan veel langer zijn. En daarmee is er dus een kans om de schade te beperken. Geruime tijd concentreerde het onderzoek zich op 2 theoretische opties. In de eerste plaats de vasculaire optie, in de tweede plaats de parenchymateuse optie. De vasculaire optie houdt in dat we snel na het ontstaan van een infarct het betreffende vat openen, zodat voorkomen wordi dat vitale hersendelen beschadigd raken. De parenchymateuse optie (parenchym = het weefsel zelf) houdt in dat we onderzoeken of bepaalde beschermende stoffen in mensen effectief zijn.

De vasculaire optie is bewaarheid geworden en nog volop in ontwik. keling. Het binnen 3 uur na het ontstaan van een herseninfarct intraveneus toedienen van hel stolseloplossende middel recombinant tissue plasminogen activator (rtPA) leidt tot een duidelijke afname van de hoeveetheld personen die na de beroerte zorgafhankelijk blijft en een toename wan het aantall mensen dat weer in behoorlijke doen thuis kan wonen. Als er 1000 patienten binmen 3 uur na het ontstaan van de verschijnselen behandeld worden, is het gevolg dat er 110 extra weer thuis kunnen wonen. Dit is binnen de geneeskunde een zeer effectieve behandeling, effectiever dan heel wat andere die we ook regelmatig toepassen. De behandeling is lastig, je moet er als behandelaar ervaring mee hebben en witsluitingscriteria moeten nauwkeurig in het oog gehouden worden. Groot probleem is de drie uurs grens. De meeste patienten komen te laat. Overigens lukt deze behandeling het best bij patiênten die rechtstreeks naar het ziekenhuis komen. Er is onderzoek verricht dat aannemelijk maakt dat toediening van het middel trPA door middel wan een catheter in een hersenslagader, de intra-arteriele toediening, effectiever is en gedurende een groter tijdsinterval, namelijk tot 6 uur, mogelijk is. Veelbelovend, maar technisch lastiger.

De parenchymateuze optie is wooralsnog niet bewarheid geworden. Er was een handvol middelen (zoals calcium antagonisten en antagonisten van excitatoire aminozuren) die veelbelovend leken. Het verhal vain de calcium antagonist nimodipine is interessant. 117988 verscheen in de New England Journal of Medicine een verslag van een Nederlands 
onderzoek bil patienten met een herseninfanct. De resultaten leken zo positief dat er internationaal een reeks onderzoeken uitgevoerd werd. die allemaal negatief uitvielen. Een gestructureerde meta-analyse die enkele resultaten wan sommige klinische experimenten samenwate suggereerde een gunstig effect mits bimnen 12 wur na het ontstaan toegediend. Reden on een onderzok te starten waibij huisartsen het middel of een placebo al in de thuissituatie toedienden. Tegelijertijd begonnen we len dan moet ik voorall de neurologe lanneke Horn noemenl aan twee gedegen gestructureerde literatuur overzichten. Het eerste gericht op het samenvatten van het aanwezige klinische bewijs, dus alle vooronderzoeken met mensen. Het tweede betrof het samenvatten van al het onderzoek bij proefieren. De resultaten waren in onze ogen opzienbarend. Het bleek dat de klinische onderzoeken eigenlijk op slechte wetenschappelijke fundamenten berustten.

In de eerste plaats, en dat was misschien wel het grootste probleem, er was zeer selectief gebruik gemaakt van de aamwezige literatuur. Onderzoekers gebruikten wat in hum stratje kwam en lieten links liggen wat er niet in paste. De klinisch wetenschappelijk onderzoekers die de eerste meta-analyse werrichtten die aantoonde dat het middel binnen 12 uurwerkte waren in deze valkuil gelopen. Het klinische onderzoek bleek begonnen na een onvolledige samenvatting var het diepexperimentele wetenschappelijk werk.

Het dierexperimentele werk was vaak van slechte kwaliteit. Er waren wel degelijk pogingen om het methodologisch beter te doen, het woorbeeld van dubbelblind onderzoek bij matten wil ik u niet onthouden. U weet dat we in de geneeskunde de methode vam dubbelblindering graag toepassen. Immers, de menselijke geest neemt graag waar wat zij wil zien. Om abjectief waarnemen te bevorderen worden experimenten zo ingericht dat de waarmemer niet weet wat de behandeling was (geneesmiddel of placebo) en de patiënt evenmin. Immers die zal ook zijin oordeel laten beinvloeden door de wetenschap dat, hij placebo of geneesmiddel heeft gehad. In het bedoelde rattenexperiment meldden de onderzoekers dat er sprake was vam dubelblindering. suggererend dat ratten in staat zijn hun oordeel over hun eigen weizin af te laten hangen van wat de ratten weten over hun behandeling.

Na het falen van calcium antagonisten bleken andere veelbelovenda stoffen evenmin gunstig. De parenchymateuse optie is zeker niet voorbij, nieuwe stoffen dienen zich aan en yoor al langer bekende stoffen. bijwoorbeeld diazepam, dient nieww onderzoek opgezet te wordem.

Naast de beschreven vasculaire en parenchymateuze benaderingen. 
waren er anderen, valk artsen uit de hoek van de geriatrie of revalidatie, die zich verdiepten in gespecialiseerde zorg voor patiënten met een beroerte. Die zorg werd verleend op zogenaamde stroke units. Eerligk gezegd weten we niet heel precies wat de noodzakelije eigenschappen van deze verpleegeenheden zijn. Vijuwel altijd is er sprake van multisiciplinalre zorg. gespecialiseerde verpleegkundigen en artsen en het werken wolgens protocollen. Een gestructureerde meta-analyse toonde aan dat deze behandeling effectief was. Zorg op een Stroke Unit leidt tot een afname var de sterfte met een kleine $20 \%$ en eveneens tot een afname van langdurige zorgafhankelijkheid met bijna $20 \%$, of het nu patienten met een lichte of ernstige beroerte betreft. Alleen maar door patiënten niet op te nemen op een gespecialiseerde stroke unit blijken er van de nooo patienten 70 extra te zijn die weer zelfstandig thuis kunnen wonen.

\section{Doen}

Nu zal ik bespreken wat wij in de gezondheidszorg voor patiënten met een beroerte doen. Dat er een grote discrepantie bestaat tussen hetgeen voorgeschreven wordt in 'ewidence based' richtlijnen en de werkelijke praktijk van de gezondheidszorg is reeds lang bekend. De praktijk heeft veel tijd nodig on de nieuwe wetenschappelijke inzichten toe te passen.

Ik schetste unet all dat de twee belangrijkste vernieuwingen in de zorg de komst van gespecialiseerde verpleegafdelingen, zogenaamde stroke units, zijn geweest en de introductie van het intraveneus toedienen van itPA.

Maar hoe effectief zijn we nu in Nederland?

In de eerste plaats die stolseloplossers, het intraveneuse rtPA. Het aantal correct behandelde patienten in Nederland is te laag. Het zouden er veel meer kunnen en moeten zijn. In theorie kom maximaal $45 \%$ van alle patiênten met een herseninfarct in armmerking voor deze behandeling. Dat is als je even alleen let op medische indicaties en contra-indicaties en veronderstelt dat alle patienten binnen de gestelde tijdscriteria in het ziekenhuis komen. Er zijn anderen die het wat lager schatten, laten we voor het gemak aanhouden dat 1 op de 3 behandeld zou kunnen worden. De praktijk is heel anders. In veel ziekenthuizen wordt geen trombolyse toegepast, in veel ziekenhuizen wel, maar is het aantal getrombolyseerde patienten laag. Naar schatting een tiental ziekenhuizen, waronder het azM, is in staat tegen de $15 \%$ wan alle patienten te trombolyseren, de meesten blijven daar ver onder. o tot $2 \%$ is geen wit- 
zondering. Het is moeilik om te schatten hoeveel patiènten daaciwerkelijk behandeld worden, maar naar mijn schatting zijn dat er in Nederland niet veel meer dan 900 . De redenen waarom dit aantal zo laag is zijn velerlei. Patienten komen te laat in het ziekenhuis. Dit komt door de aard van de ziekte (geen pijn, uitval die tot verlamming of spraakstoomis leidt), onbekendheid met de noodzaak tot snelheil en de tussenkomst van de huisarts. Dan is er vertraging in het transport naar Eerste Hulp. Verder is er het probleem van de vertraging in het ziekenhuis, een patient moet smel onderzocht worden, er dient ogenblikkelijk een CT scan vervaardigd te worden, pas na beoordeling kan de behandeling starten. De neuroloog is net bezig met een patient met rugpijn en kan niet ogenblikkelijk rtPA toedienen. Allemaal mogelijke obstakels waardoor patiënten niet of te laat behandeld worden. Voor deze behandeling geldt het adagium: "time is brain'. Als wij er met zijn allen in slagen alle daarvoor in aanmerking komende patienten te trombolyseren praten we over vele duizenden patienten die behandeld kunnen worden. De winst zou fors zijn. Immers, als er van de 30000 patienten per jaar 10,000 behandeld kunnen worden, dan zijn er meer dan 1000 patienten die in goede staat thuis kunnen komen en niet naar een ver. pleeghuis hoeven te gaan of aan de beroerte sterven.

Ik zei al 'time is brain'. De meeste patiënten die getrombolyseerd worden, worden tussen de 2 en 3 uur na het ontstaan van het infarct behandeld. Als je binnen 1,5 uur behandelt is het effect ruwweg 1,5 keer zo groot als tussen 1,5 en 3 uur. Met andere woorden, we moeten niet meer patienten binnen de drie uur behandelen, mar veel meer binnen 1,5 uur. Voorwaar geen geringe opgave.

Hoe doen we het met betrekking tot de stroke units? Het aantal Stroke Units neemt toe, maar nog lang niet alle patiënten met een beroerte worden op een gespecialiseerde eenheid opgenomen. Naar schatting een kwart van de patienten heeft nog geen toegang tot die zorg. Er is een consensus richtlin over wat een stroke unit in moet houden, het is zeker dat een aantal stroke units nog niet op het gewenste kwaliteitsniveau is. Hoewel ik dat niet geheel met gegevens kan onderbouwen steek ik mijn nek toch maar uit en beweer dat de helft wan de patienten met een beroerte in Nederland nog niet de kwalitatief juiste acute zorg op een stroke unit krijgt. Dat betekent nogal wat. I beschreef net dat de kansen op goed herstel met een kleine $20 \%$ toenemen na behandeling op een stoke unit. Volgens mijn schattingen krijgen mogelijk 15000 mensen in Nederland niet deze correcte behandeling. Dat betekent dat als alle patienten acuut opgenomen zouden worden op 
een verpleegheenheld die aan alle kwaliteitseisen woldoet, er jaantijks in Nederland ruim 1000 patiënten extra zouden zijn die weer onafhankelijk van zorg thuis kumnen wonen. Imijn interpretatie van getallen die gedeettelijk gepubliceerd zijn en van mondelinge mededeling ar. C. Franke. (NHS).

Ook in de preventie doen we niet wat wetenschappelijk aangetoond effectief is. Vooral ziln er hiaten in de behandeling wan hoge bloeddruk en cholesterol. Als ik een en ander bij elkaar optel dan zijn er goede mogelijkheden om 1000 tot 2000 personem jaarlijks weer onafhankelijk van zorg thuis te krigen. Dit is de optelsom van wat we nu laten liggen op het gebied van de zeer acute stoiseloplossende behandeling, op het gebied wan toegewijde en gespecialiseerde stroke unit zorg en de moge. lijkheden op het gebied van de preventie.

Ook all is dit een overdreven gunstige schatting en zal het effect in de werkelijkheid veel minder spectaculair zijn, dit geeft toch aan dat er de komende jaren nog veel gedaan zal moeten worden aan de organisatie en kwaliteit van de zorg in Nederland. Overigens betekent dit geen financieel grote investering. Met beperkte middelen, maar vooral door het anders in te richten kunnen we deze resultaten bereiken.

\section{Willen}

Over het 'willen' zal ik niet heel ver uitweiden. Volgens Aristoteles is elke vaardigheid en wetenschap gericht op iets goeds. Aitsen vormen geen uitzondering. Mede daarom heeft een arts zjin beroep gekozen en de eed van Mippocrates bevestigt dat. Voor zorgverlenende instanties geldt mutatis mutandis hetzelfde. Deze orgarisaties zijn er om mensen te helpen. Fraaie mission statements geven dat weer. Voor alle duidelijkheid: een mission statement is niet verkeerd. Immers, het is nuttig om te expliciteren wat je doelstellingen en waarden zijn. Waar het om gaat in jouw vak. Waarstat de instelling voor Personen en organisaties die hun doel willen bereiken moeten hun doel definieren.

Dan zijn er drie elementen die ik naar woren will halen: informatie, beslissings bevoegdheid en beloningsstructuur.

Ik stel me voor dat we werkgroepen hebben bestaande uit artsen, verpleegkundigen, fysiotherapeuten, die verantwoordelijk zijn woor de behandeling wan een bepalde categorie patiënten. Een woor de hand liggende categorie vormen onze patienten met een cerebrowascualaire aandoening, ongeveer 450 per jaar. Deze werkgroep moet over de juiste informatie beschikken: kijgt elke patient de gewenste behandeling volgens protocol, op tijd? Worden de juiste beoordelingen verricht, ik doel 
dan op slikproblemen, het weer uit bed komen en al die andere, eenvoudige maar zo belangrijke zaken. De werkgroep moet ervoor zorgen de juiste gegevens, en dit zijn indicatoren over het handelen, te bezitten en daarnaar te handielen. We maeten gegevens over de resultaten van onze behandeling hebben. Dan moet de groep ook beslissingsbevoegdheid hebben, dit mag niet naar een hogere management lag geschoven worden. En vervolgens moeten goede resultaten beloond worden. Daarbij gaat het niet noodzakelijkerwijs om bonussen, dala kunnen zeer gevaarlijke kanten aan zitten, maar resultaten moeten duidelijk zijn en gewaardeerd worden of er moet bijgestuurd worden. De gezondheidszorg loopt hierin absoluut niet vooraan. In feite heeft bijna elke andere activiteit die we in de maatschappij verrichten wel een dergelijk systeem van prestatie metingen.

De drie zojuist genoemde elementen: informatie, beslissingsbevoegdheid en beloningsstructuur worden ook wel de drie poten van een kruk genoemd. Drie poten zijn het minimum om stabiliteit te waarborgen

Wat ik zojuist schetste over de driepotige kruk is geldig binnen de organisatie maar ook in de maatschappij. Waarom niet een instelling die erin slaagt $20 \%$ van zijn patienten met een herseninfarct te trombolyseren een hogere beloning geven dan de instelling die slechts $2 \%$ van zijn patiënten behandelt? Waarom niet belonen als patienten binnen 1,5 uur getrombolyseerd worden, in plaats van na 1,5 uur? De winst voor de individuele patiënt is groot, de kans dat iemand weer voor zichzelf kan zorgen neemt sterk toe met elke tijdwinst.. $U$ weet het 'time is brain'. Ik pleit hiermee voor het ontwikkelen van prestatie afhankelijke DBC prijzen.

Als woorzorg moet auditing en eventueel certificatie komen, de betreffende stroke moet met indicatoren komen en laten zien dat de prestaties reëel zijn.

\section{Kunnen}

Tenslotte het kunnen. $1 k$ bespreek in de eerste plaats over wat in het Engels 'enablers" genoemd worden. Welke factoren kunnen een rol spelen teneinde mogelijk te maken wat we kunnen maar kaarblijkelik niet doen?

In de tweede plaats bespreek ik ower hoe naar mijn idee de zorg voor deze belastende ziekte beter georganiseerd kan worden.

Wat betreft 'enablers' noem ik in de eerste plats informatie en Communicatie technologle. In mijn vorige positie in het AMC heb ik 
daarmee uitgebreid kennis kunnen maken. Opwallend zijn de grote mogelijkheden in theorie, het in feite geringe gebuik in de praktijk en het grotendeels ontbreken van implementatie onderzoek in deze. We gaan op grote schaal de komende jaren nieuwe technologie introduceren die vrijwel niet onderworpen is geweest a an kritische evaluaties. Ik praat nu over het wetenschapsgebied van de medische informatiekunde. We weten niet waar de grote winst voor de gezond heidszorg precies te verwachten valt. We weten niet waarom zoveel $1 \mathrm{CT}$ implementaw tieprojecten falen, ook in de gezondheidszorg. Er is veel diffuus verspreide kennis hierover, verelal in bezit van consultancies die niet de neiging hebben hun inzichten in het publieke domein te openbaren. I $k$ noem twee triomfen van het toepassen van informatie en communica. the technologie in de zorg. De eerste triomf betreft het op grote schaal beschikbaar zijn van wetenschappelijke informatie, ik doel op via het intermet toegankelike bestanden zoals pubmed en de cochrane Database. Er verschijnen dagelijks duizenden wetenschappelijke publicaties waarvan de inhoud maar met moeite tot de praktijk wan de zorg doordringt. Het is uitgesloten dat lemand dat all lezend bij zou kunnen houden. Een internationaal samenwerkingsverband van duizenden onderzoekers beoordeelt nu voortdurend op gestructureerde wijze de literatuur en vat deze samen. Ik spreek over de International Cochrane Collaboration. Pubrred is een door de Amerikaanse overheid gefinanclerd systeem met informatie over medische wettenschappelijke literatuur kan vinden. Onze arts-assistenten worden geacht aan het eind van hun opleiding in staat te zijn problemen in het dagelijks klinische handelen te baseren op wetenschappelijk inzicht. Wekelijkse CAT sessies (critical appraisal topics) helpen hen daarbij om dat te leren. Een vraag uit: de praktijk wordt aan de hand van een literatuur zoekactie in een groot bestand, beantwoord. Een antwoord op de vraag wordt geformuleerd en ande afdeling gepresenteerd.

Een tweede triomf betreft de beschikbaarstelling van uitslagen van aanvullend laboratorium-en radiodiagnostisch onderzok via de computer. Deze functionaliteit bestatat al jaren en wordt geleidelijk uitgebreid. Hier ga ik niet verder op in.

De laatste jaren zijn we getuige van de queeste naar het electronisch patienten dossier. Ik versta daar een bundel functionaliteiten onder, een verzameling van verschillende functies dus. Na jaren van pogingen begint het er nu geleidelijk van te komen. Een bewezen effectieve toepassing is de beslissingsondersteuning. Vijj veel wetenschappelijk onderzoek heeft aangetoond dat het presenteren van relevante infor- 
matie op het moment dat de arts een medische beslissing moet nemen tot een verbetering van het handelen kan leiden. Met gunstige resultaten niet alleen woo het medisch handelen maar ook woor de uitkomst van de patient. Eerlijkheid gebiedt me te zeggen dat enkele van de succesvolle beslissingsondersteunende systemen niet elektronisch waren maar bijvoorbeeld een kaartenbak met ruitertjes op kaarten van patienten die een vaccinatie moesten ondergaan. Het elektronisch ordermanagement is een techniek waarbij de arts hulponderzoek niet meer zoals nu met handgeschreven formulieren aanvraagt maar dat online doet. Het systeem kan relevante onderdelen van protocollen of richtlijnen te voorschijn te toveren, beslissingsondersteuning derhalve. De uitvoerende afdeling krijgt de beschikking over patiënten informatie en het plannen van hulponderzoek op een voor de patiënt vriendelijke wijze wordt bevorderd.

De radilologie afdeling is al in heel veel ziekenhuizen succesvol gedigitaliseerd, recent bij ons, en op enkele kinderziekten na is dit een groot succes. Foto's zijn niet vaak meer weg (tot onze verbazing blijken echter ook digitale foto's te kunnen verdwijnen), en zijn op verschillende werk plekken tegelijkertijd aanwezig.

Naast de hierboven genoemde functies is er dan ook een registratie functie noodzakelijk. Op onze medium care is die nu aanwezig, in een wat primitieve vorm, maar de trend is gezet. Het digitaal opslaan van bij vookeur gestandaaardiseerde patientenkarakteristieken, beloop en behandeling heeft een aantal voordelen. Gecompliceerdere systemen, die aangeduid worden met termen als 'Patient tracking en work flow management' hebben zich bewezen in industriële organisaties. Hier worden systemen ander versta.an waarmee je diagnostische trajecten en behandelingen kunt plannen, weet welk onderzoek instaat en welke uitslagen verwacht worden. Het bewijs dat ook de uitermate geindividualiseerde processen in de gezondheidszorg hier effectiever door kunnen verlopen moet nog geleverd worden.

Een andere 'enabling' factor is de juiste organisatle. Als we aan de toestand van een jaar of 10 geleden denken met betrekking tot de behandeling van een patiënt met een beroerte, bijkt er zeer veel ten gunste veranderd te zijn. Het was in die tijd onder zorgverleners algemeen bekend dat er te weinig acute bedden waren. De acute interventie behandelingen begonnen zich af te tekenen. Maar de mogelijkheden waren er niet. Schrijnende verhalen over patienten die in zeer veel ziekenhuizen geweigerd werden door gebrek aan opname capaciteit te over Geconfronteerd met deze problematiek, en wast besloten werder te 
werken aan de acute behandelingsmogelijkheden hebben we met het management gesproken. Men wist op dat moment niet van de pijnlijke tekorten en noemde alleen maar cen bedbezettingspercentage van $85 \%$, dus woldoende ruimte. Volledig voorbijgaand aan de variatie die de praktijk nu eenmaal kenmerkt. Hollen of stilstaan, dan weer geen patienten, dan weer een aantal tegelijkertijd. Je moet dus wat ruimte hebben, overcapaciteit, lege bedden. Waar electieve zorg voor individuele patienten te plannen is, denk aan heup-en krige-operaties, kan dat op individueel niweau niet woor patienten met een beroerte. Maar op groepsniveau is er weer heel behoorlijk te plannen. We weten ongeveer hoeveel patienten zich zullen melden en wat de variatie in zorgvraag is. We zijn toen verder gegaan met het vernieuwen van de zorg. Een werw pleeghuis bleek geinteresseerd en wilde een grotere rol spelen bij de eactivatie van patiënten met een beroerte. Zo slaagden we erin een effectieve zorgketen rond het ziekenhuis op te zetten (stroke service) met opname garantie voor patienten uit de regio, kortere verblijfduur in het ziekenhuis, en een gespecialiseerde afdeling binnen het ziekenhuis (stroke unit). I heb dit in het AMC gedaan, hier in azM gebeurde iets vergelijkbaars. De trombolyse werd mogelijk dankzijde organisatarische en logistieke verbeteringen

\section{Beter kunnen}

Hoe kunnen we het beter doen?

Ik splits mijn antwoord in twee delen: verdere ontwikkeling van het medische handelen, eigenlijk het wetenschappelijk onderzoek, en het anders inrichter van de zorg.

Endovasculaire behandelingen. Na alle verworvenheden van intraveneuze behandeling met $r$ PA, zijn er argumenten dat het intra-arterieel toedienen wan stolseloplossers effectiever is en minder tijdsbeperkingen heeft. Dat gaat via een catheterisatie in de lies waarbij een slangetje tot in die hersenwaten opgeschoven wordt. Aan ons de taak om ook daad. werkelijk te bewijzen of dit onomstotelijk zo is. Als je deze technieken goed in huis hebt, dan worden weer nieuwe ontwikkelingen mogelijk. Waarom niet met mechanische middelen, 'appelboortjes' of 'schepnet. jes' de vaten geopend? We hebben een succesvolle samenwerking met de afdeling radiodiagnostiek voor het behandelen wan patienten met een geknapt aneurysma en hopen nu ook dit aspect van behandeling verder te ontwikkelen. Zo ook aanwultende technieken zoals de functionele Magnetic Resonance Imaging (fMRl), die het wellicht mogelijk maakt onze behandelingen veel gerichter toe te passen. 
Parenchymateuze behandelingem blijuen lonken. Immers een beschermende stof toedienen zonder veel bijwerkingen is heel aantrekkelijk. Diazepam dient werder onderzocht te worden.

Nu organisatie. Naar mijn mening is hier heel weel winst te halen. Ik heb de volgende voorstellen die kunnen leiden tot een grotere effectiviteit.

Gespecialiseerde regionale netwerk organisaties. Concentreer de behandeling van beroerten in enkele centra. Laat niet elke neuroloog of elk centrum het ook min of meer doen, maar specialiseer. Hier bouwt men de expertise op die nodig is. De systemen en processen raken ingespeeld op het acuut zorgverlenen. We weten dat dergelijke focused factories effectiever kunnen zijn en betere kwaliteit kunnen leveren. Neurologen uit participerende centra doen naar wens ook trombolyses in het centrum, en nemen de patiënt na stabilisatie op eigen stroke service over. Daar wordt verder naar oorzaak gezocht en de volle aandacht aan revalidatie besteed. Binnen deze centra moet de operationele gang van zaken verbeterd worden. Heldere afspraken en protocollen, verantwoordelijkheden benoemen, het invoeren van indicatoren die getalsmatig aangeven waar de problemen zitten. Ik pleit daarom voor een grondige analyse van de huidige processen en een al of niet volledig herontwerp hiervan.

Aan de stroke services zijn case managers werbonden die gerichte aandacht besteden aan stille gebreken en secundalre preventie. De mantelzorg wordt gesteund.

Technologisch-organisatorische vernieuwingen. Waarom experimenteren we niet met eerste hersenhulpen waar een CT of MRI staat? Alles om de snelheid te bevorderen. Of radicaler: waarom geen hersenrenwa. gen met een CT scan erin? Technisch kan het, model droogkap.

of de intra-arteriele benadering met bijzondere instrumenten verder ontwikkelen. Hierbij is de input vanuit medisch-technologisch georienteerde bedrijven of universiteiten noodzakelijk.

Flexibele beloningsstructuur. Richt een systeem in dat expliciet vroenge en kwalitatief hoogstaande behandeling van patienten met een beroerte stimuleert. Maak DBC prijzen afhankelijk van kwaliteitsparameters, zoals tijd tussen ontstaan beroerte en behandeling.

voorlichting bevolking. Campagnes gericht op het bewustworden van het belang een beroerte te herkennnen en direct te handelen. Gebruik van de FAST test, een simpel 3 vragen lijstje warmee beroerten onderkend kunnen worden.

Met de hierboven genoemde matregelen is het naar mijn idee moge- 
lijk een winst van meer dan 1000 extra zorgonafhankelije patienten na een beroente te reatiseren. Hoewel nogal wat van mijn ideeen draistisch zijn, is de gedachte dat we de zorg zodanig verbeteren dat er ongeveer 2 , mogelijk 3 verpleeghuizen in Nederland overbodig worden, zeer aantrekkelijk.

Ik weet zeker dat als wij willen, wij kunnen doen wat we weten.

\section{Onderwiijs}

De Universiteit Masstricht is beroemd vanwege het innovatieve onderwijs. Feit is wel dat studenten deze manier van onderwijs zeer op prijs stelien. Ik heb op beschelden wijze kennis gemaakt met de produkten van deze opleiding doordat we hier opgeleide co-assistenten hebben. Dat is een genoegen. er zijn er altijd een paar die op een prikkelende manier vagen stellen. Het succes van het onderwijs in Maastricht is een kostbare verworvenheid die gekoesterd en uitgebouwd moet worden. In het licht van de toenemende strijd om de gunst van de student heeft Maastricht een uitstekende positie die op zijn minst gehandhafd dient te worden. Cezien mijn ervaringen met onderwijs uitvoering en organisatie verwacht ik in de toekomst ook in Maastricht de kans te krijgen hieraan bij te mogen dragen.

\section{Onderzoek}

Waar ik hiervoor ower patiëntenzorg leek te praten deed ik dat in feite ook over onderzoek. Alle voorstellem dienen onderzocht te worden, van het ontwikkelen van mechanische stolselvangers tot een experiment met ambulance met CT of prestatie afhandelijke DBC's. Ik heb dus ook over onderzoek gesproken, onderzoek is immers onlosmakelijk van de zorg in een academisch centrum. Binnen onderwijs is problem based learning" het adagium, in het onderzoek moet dat ook zo zijn. "Problem based research' is in staat te mobiliseren wat we allemaal aan kennis en expertise in huls hebben. Er zin unieke mogelijkheden in Mastricht. Die kunnen bewaaheid worden mits de bestuurders hun verantwoordelijkheid nemen en tot een fusie van ziekenhuis en faculteit komen, ook Maastricht heeft recht op een universitair medisch centrum. De beloften van samenwerking met Euregionale partners zijn groot. Binnen de onderzoeksinstituten Hersenen en Gedrag en CARIM kan de neurologie die synergie met andere groepen prachtig ontwikkelen. In het zlekenhuis zijn we onderzoeks en patientenzorg activiteiten met de neurochirurgie en de afdeling KNF aan het afstemmen, binnen de eenheid klimische neurowetenschappen. 
Ik heb zojuist aandacht besteed aan een van onze aandachtszwaartepunten, de vasculaire ziekten. Een tweede zwaartepunt wordt op dit moment gevormd door de epileptologie. $\mathrm{Er}$ is al een 10 jaar bestaande samenwerking met het Epilepsie Instituut Kempenhaeghe te Heeze. Dit Insituut is uitgegroeid tot een toonaangevende instelling op het brede gebied van epilepsie zorg en onderzoek. Op een aantal gebieden is de samenwerking tussen UM en KH zeer succesvol gebleken, tot beiderzijds voordeel en vooral tot voordeel van de patient. Ik noem gedragsstoornissen bij kinderen, medicatie trial5, psychosociaal en basaal onderzoek. De samenwerking is nog onvoldoende geslaagd op het gebied van de patiëntenzorg bijepilepsie chirurgie, op het gebied van de klinische neurofysiologie en de beeldvorming. Op beide gebieden zijn er kansen te over, en we willen die kansen de komende jaren ook gaan benutten. Intensieve en productieve samenwerking tussen Kempenhaeghe en azM / UM biedt kansen voor verdere ontwikkeling van de epilleptologie die nergens anders in Nederland aanwezig zijn.

Naast vaten en epilepsie willen we bewegingsstoornissen imeer ruimte geven. De ontwikkelingen op het gebied van Deep Brain Stimulation, de mogelijkheden voor beeldvorming, alandacht woor cog. nitie, de neuro-immunologie, de ervaringen en het onderzoek bij spasticiteit zijn alle argumenten om dit gebied ontwikkelingskansen tegeven. 


\section{Dankwoord:}

Tot slot een dankwoord. De universiteit Mastricht en het academisch zekenthuis Maastricht dank ik voor de geboden mogelijkheden. Het is een eer en een uitdaging om verder te werken bij deze gerespecteerde afdeling neurologie aan dit nog jonge instituut. De afdeling neurologie heeft bewonderenswaardig gepresteerd in die $25 \mathrm{jaar}$. Vanuit een eermans neurologie praktijk heeft de pionierende staf een groot onderzoeksresultaat en hoog ontwikkelde patiẻntenzorg opgebouwd. We staan voorwaar op dit moment niet met lege handen.

ik dank de staf van de afdeling neurologie voor open opstelling ten opzichte van mijn komst. Dat het niet altijd eenvoudig is begrijp ik volledig, nieuw hoofd nieuwe keuzen. Maar er is geen andere mogelijkheid, er moet gekozen en veranderd worden. Dat betekent concentratie en convergentie op een beperkt aantal lijnen teneinde op minder gebiiden een betere positie te bereiken en succesvoller te opereren, in samenwerking met partners binnen de klinische neurowetenschappen, de UM azM, de regio en daarbuiten. Ik spreek mijn vertrouwen uit in de getalenteerde stafleden van de afdeling neurologie die in stat zullen zijn effectieve onderzoeksgroepen te vormen. Ik dank de assistenten woor hun bereidheid mij als opleider te accepteren en samen te werken aan de opleiding. Ook dit is zoeken, we zijn al begonnen met enkele vernieuwingen in de opleiding, zoals aandacht voor het basis vak van de klinische epidemiologie, een boekenclub en een onderwijsvisite die nog verder ontwikkeld moet worden.

Ik dank de verpleging voor hun bereidheid om voortdurend naar verbetering en vernieuwing te blijven zoeken. Datzelfde geldt voor de polikliniek, we behandelen veel patiënten, we weten dat we dat beter kunnen doen en zijn nu bezig die ideëen te witt te werken.

ik dank Thera van Lieshout, de vrouw die alles weet van het reilen en zeilen van de afdeling neurologie in een zeer complexe omgeving.

Tot slot mijn gezin. in de eerste plaats Nina, en naturilik ook Tastha, Sarah en Jur. Maastricht lijkt verder weg dan Minnesota. Jullie hebben mij gevolgd op de onregelmatige momenter dat ik echt vond dat de tijd rijp was voor een grote verandering. Mijn dank voor jullie moed en bereidheid het avontur aan te gaan, laten we samen genieten van de moole ongeving. 
